\title{
The binding of labelled basic proteins by boar spermatozoa
}

\author{
H. D. M. Moore and K. G. Hibbitt \\ Institute for Research on Animal Diseases, Compton, Newbury, Berkshire
}

\begin{abstract}
Summary. Seminal plasma basic proteins were labelled with ${ }^{131} \mathrm{I}$. The efficiency of the labelling was studied by superimposing protein density traces on a radioactive fractionation plot. These labelled proteins were incubated with spermatozoa and shown to bind more readily to spermatozoa from boars after the removal of the vesicular glands than to spermatozoa obtained from their normal litter mates. Most of the labelled protein became bound to the membranes which were isolated by sucrose density gradient centrifugation. The membranes were separated into two bands which equilibrated at the relative densities of $1 \cdot 150$ and $1 \cdot 165$. These fractions consisted of membrane vesicles of different size; the smaller band on the gradient, which equilibrated at $1 \cdot 165$, consisted of denser membrane material.
\end{abstract}

\section{Introduction}

The proteins of the accessory sex gland secretions from several mammals have been shown to coat epididymal spermatozoa (Weil \& Finkler, 1958; Matousek, 1964; Hathaway \& Hartree, 1963). These sperm-coating antigens, which are mainly of seminal vesicle origin, are not readily removed once they have been adsorbed by the spermatozoa. Boursnell \& Coombs (1966) have evidence that a proportion of boar seminal plasma proteins is firmly adsorbed on the sperm surface and only partly removed by washing. There are indications that basic proteins can increase the permeability of biological membranes (Ryser \& Hancock, 1965; Drew \& McLaren, 1970; Hibbitt \& Benians, 1971), and it is possible that seminal vesicle basic proteins may have a similar effect on the membranes of spermatozoa. Boar seminal plasma has a high concentration of basic proteins of seminal vesicle origin (Lavon \& Boursnell, 1971), which could make the sperm membrane susceptible to damage during the cooling and freezing processes required for long-term semen storage. Boar spermatozoa cooled to temperatures below $10^{\circ} \mathrm{C}$ show an irreversible loss of motility (Polge, 1956), which may be associated with the haemagglutinin basic protein produced by the seminal vesicles (Roberts et al., 1974). By using boars which have had their seminal vesicle glands surgically removed (Davies et al., 1975), a preparation of semen can be obtained free of seminal vesicle secretion. In the present study, a fraction containing most of the basic proteins in boar seminal plasma was labelled with iodine-131 to establish whether binding between boar spermatozoa and the seminal vesicle basic proteins was occurring on contact.

\section{Materials and Methods}

\section{Vesiculectomy}

Large White boars of good breeding potential were selected from the Institute minimal disease herd. Surgery was performed at 4-8 months of age as described by Davies et al. (1975) and the boars were then allowed to recover fully before being trained for semen collection. Intact boars from the same litter, and therefore of similar age and genetic background, were retained as controls. Two intact and three vesiculectomized boars were used.

\section{Semen collection}

Semen was collected by the gloved-hand technique (Hancock \& Hovell, 1959) through gauze into a prewarmed vacuum flask at $30^{\circ} \mathrm{C}$. Collections were made from all boars at weekly intervals. 
To obtain seminal plasma samples, the spermatozoa were removed from the semen immediately after collection by centrifugation at $10,000 \mathrm{~g}$ for $30 \mathrm{~min}$ at $25^{\circ} \mathrm{C}$. The seminal plasma was carefully removed from the sedimented spermatozoa, filtered and stored at $-20^{\circ} \mathrm{C}$. Regeneration of the seminal vesicle glands was monitored by measuring the citrate (Moellering \& Gruber, 1966) and protein (Layne, 1957) concentrations in the seminal plasma.

\section{Separation of the basic protein fraction}

Nelson \& Boursnell (1966) and Boursnell \& Briggs (1969) have demonstrated that boar seminal plasma proteins may be separated by gel filtration into two main fractions, a large molecular weight acidic fraction and a smaller molecular weight fraction containing the majority of basic proteins. To obtain a basic protein fraction to label with iodine-131, intact boar seminal plasma was dialysed overnight in $0.1 \mathrm{M}$ acetate buffer, $\mathrm{pH} 4.0$, and $3 \mathrm{ml}$ fractionated on a G-200 Sephadex column (Pharmacia, Uppsala), which had been previously equilibrated with the same buffer, and run at a flow rate of $10 \mathrm{ml} / \mathrm{hr}$. Fractions $(2.5 \mathrm{ml})$ of the eluate were collected and the protein monitored at $280 \mathrm{~nm}$ in a Uvicord II (LKB Instruments Ltd, Croydon). The initial higher molecular weight acidic protein peak was discarded while the whole of the basic protein peak was collected, the fractions combined and dialysed against $0.1 \mathrm{M}$-tris- $\mathrm{HCl}$ buffer, $\mathrm{pH} 7.5$ (Text-fig. 1). To remove any acidic proteins still present this fraction was loaded on a DEAE-Sephadex column (Pharmacia) equilibrated and eluted with more $0 \cdot 1 \mathrm{M}$-tris- $\mathrm{HCl}$ buffer, $\mathrm{pH} 7 \cdot 5$. The protein collected in the eluate was then used for labelling with iodine-131.

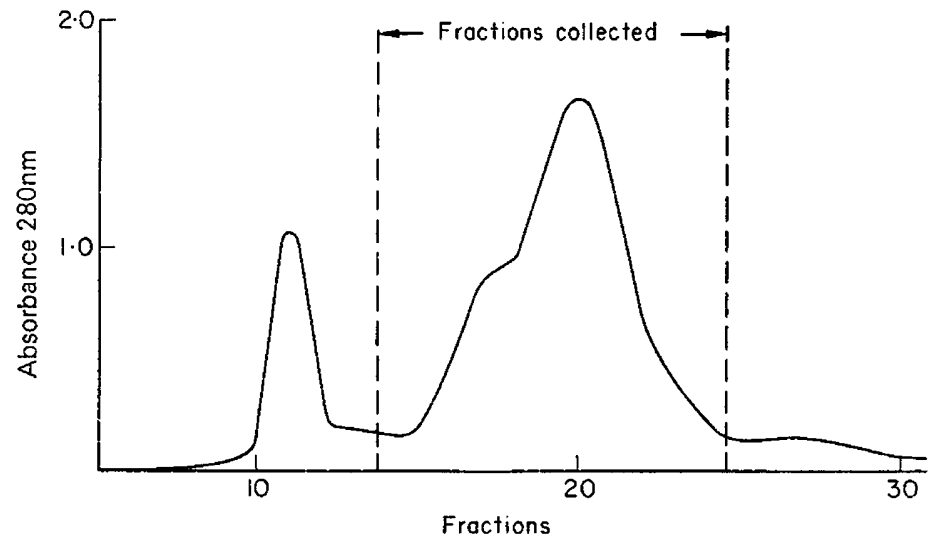

Text-fig. 1. Protein profile of boar seminal plasma separated on G-200 Sephadex, showing the position of the protein peak subsequently run on DEAE-Sephadex and then labelled with iodine-131 (see text).

\section{Labelling of the basic protein fractions}

A labelled basic protein fraction was prepared by the method of Hunter \& Greenwood (1962). Aliquots $(5 \mu \mathrm{g}$ in $20 \mu \mathrm{l})$ of basic protein were reacted with $5 \mathrm{mCi}(125 \mu \mathrm{l})$ of iodine-131 (Radiochemical Centre, Amersham) using chloramine T ( $88 \mu \mathrm{g}$ in $20 \mu \mathrm{l})$ as an oxidizing agent. Unreacted iodine-131 was separated from labelled protein by passing the mixture down a small column packed with G-50 Sephadex (Pharmacia) equilibrated and run with 0.1 M-sodium barbitone buffer, pH 8.6. The protein was recovered in the void volume in two $1-\mathrm{ml}$ fractions, stored in $0 \cdot 1-\mathrm{ml}$ aliquots at $-20^{\circ} \mathrm{C}$, and used within 1 week. The efficiency of iodine-131 incorporation was between 15 and $20 \%$, giving a specific activity for the labelled protein of $100-150 \mu \mathrm{Ci} / \mu \mathrm{g}$.

\section{Characterization of labelled protein}

Labelled and unlabelled protein fractions were compared by disc electrophoresis on $7.5 \%$ polyacrylamide gels buffered at $\mathrm{pH} 7 \cdot 5$ with $0 \cdot 1 \mathrm{M}$-tris- $\mathrm{HCl}$ containing $6 \mathrm{M}$-urea. The samples of 
protein, labelled and unlabelled, were placed at the anode of the gels and subjected to electrophoresis for $60-90 \mathrm{~min}$ at $5 \mathrm{~mA} /$ tube. At the end of the run the gels were immediately scanned at $280 \mathrm{~nm}$ (Gilford Instruments, Ohio). The gels containing the labelled proteins were frozen on solid $\mathrm{CO}_{2}$ and sliced into $2-\mathrm{mm}$ sections which were then placed in vials containing $10 \mathrm{ml}$ double-distilled water. After diffusion for $2 \mathrm{hr}$ the radioactivity of the sections was counted (Philips Gammamatic, Holland). The gels containing unlabelled protein were fixed in $5 \% \mathrm{TCA}$ at $60^{\circ} \mathrm{C}$ and stained with amido black.

\section{Labelling of seminal plasma}

The ${ }^{131} \mathrm{I}$-labelled basic protein $(6 \mu \mathrm{Ci}$ in $0 \cdot 1 \mathrm{ml})$ was added to $10 \mathrm{ml}$ normal seminal plasma to give a minimum mean specific activity of $15 \mathrm{nCi} / \mathrm{mg}$ protein.

\section{Experimental procedure}

Incubation of spermatozoa. Duplicate 5-ml aliquots of semen collected from either a normal boar or from a vesiculectomized boar were centrifuged at $700 \mathrm{~g}$ for $10 \mathrm{~min}$ while a determination of the sperm number was made (Neubauer double counting chamber). The seminal plasma supernatant was removed by aspiration, and the sedimented spermatozoa gently resuspended in labelled normal seminal plasma at $30^{\circ} \mathrm{C}$ with a Pasteur pipette. The volume of seminal plasma added was such that the sperm concentration was $4 \times 10^{8} / \mathrm{ml}$. The resuspended spermatozoa were incubated with shaking for $30 \mathrm{~min}$ at $30^{\circ} \mathrm{C}$ in small bijou bottles placed in a metabolic water bath. At the end of the incubation, the resuspended semen was washed five times at $25^{\circ} \mathrm{C}$ in successive $10-\mathrm{ml}$ vols of 0.25 M-buffered sucrose solution, $\mathrm{pH} 7 \cdot 5$. Between the washes the spermatozoa were centrifuged at $700 \mathrm{~g}$ and resuspended as gently as possible to prevent damage. The number of spermatozoa lost in the washings was counted. After the fifth and final wash the sperm pellet was resuspended in 0.25 M-sucrose solution. These spermatozoa and each successive washing were counted for radioactivity (Philips Gammamatic). The specific activity (ct/10 $0^{8}$ spermatozoa) was calculated and corrected for decay of the isotope.

Separation of membranes. Spermatozoa from boars without seminal vesicles were incubated with labelled normal seminal plasma as described above. The final washed spermatozoa were centrifuged at $10,000 \mathrm{~g}$ for $10 \mathrm{~min}$ and then resuspended in a sucrose solution of relative density $1 \cdot 13$. This sperm suspension was then frozen and thawed twice before being homogenized with twenty up-and-down strokes of a Potter-Elvehjem homogenizer. The homogenate was centrifuged at $10,000 \mathrm{~g}$ for $10 \mathrm{~min}$ and the supernatant removed and placed on a continuous sucrose gradient, relative density $1 \cdot 13$ to 1.19. The gradient was centrifuged for $17 \mathrm{hr}$ at $80,000 \mathrm{~g}$ on a Beckmann $25 \cdot 1$ swing-out rotor. After centrifugation the membrane bands could be seen and these were removed on $0.5-\mathrm{ml}$ aliquots. From these fractions the refractive index (Abbey refractometer) and radioactivity (Philips Gammamatic) were determined. The fractions containing the membrane bands were fixed in glutaraldehyde buffered at $\mathrm{pH} 7.0$ for $1 \mathrm{hr}$ at room temperature, and then post-fixed in osmium tetroxide for $1 \mathrm{hr}$ at $5^{\circ} \mathrm{C}$ before being processed for electron microscopy.

\section{Results}

\section{Polyacrylamide gel electrophoresis of labelled/unlabelled proteins}

Labelled and unlabelled protein fractions showed a similar distribution of bands on polyacrylamide gels suggesting that labelling with ${ }^{131} \mathrm{I}$ did not produce an obvious change in the protein characteristics. A protein density trace and a radioactive fractionation plot for a gel loaded with labelled protein are shown in Text-fig. 2 . The radioactivity maximum corresponded with the main protein peak shown by the $280 \mathrm{~nm}$ density trace and the staining pattern. There was no protein at the anode of the gel, indicating that the fraction was composed of only basic components. 


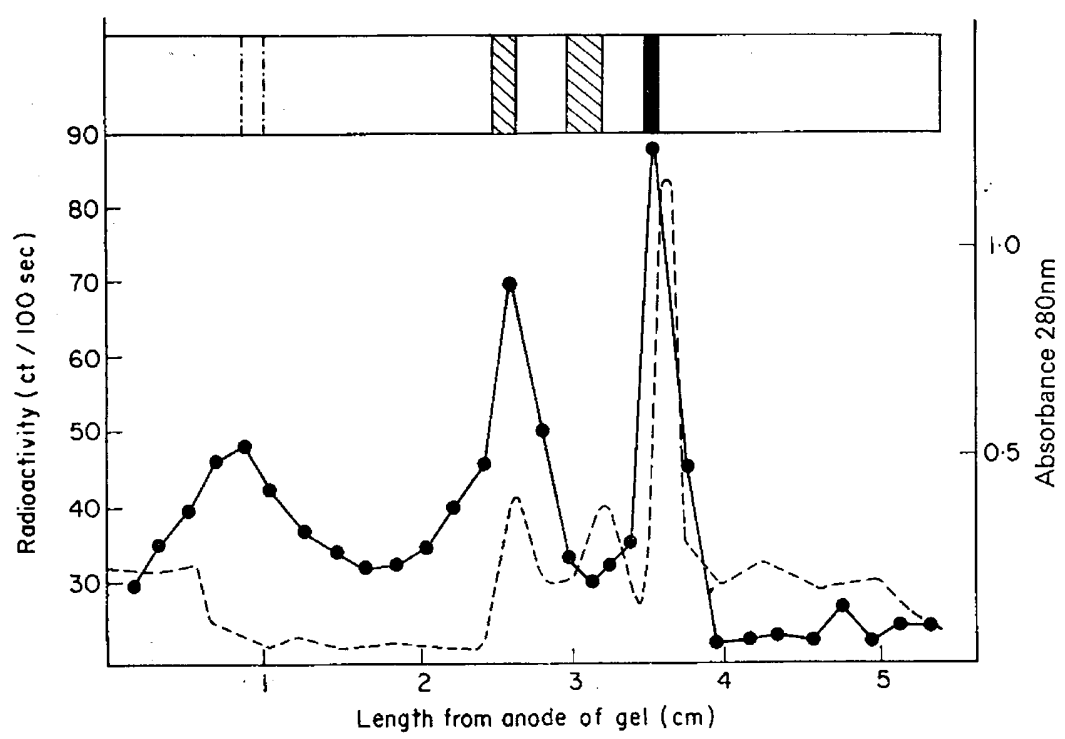

Text-fig. 2. Radioactive fractionation $(\bullet)$ of a polyacrylamide gel, $7 \cdot 5 \%, \mathrm{pH} 7 \cdot 5$, loaded with boar seminal vesicle basic protein labelled with iodine-131, and a protein density trace (--) and staining pattern for gels run under identical conditions with unlabelled basic protein.

\section{Seminal vesicle proteins binding to spermatozoa}

Significantly $(P<0.01)$ more labelled protein bound to spermatozoa from vesiculectomized boars than to spermatozoa from intact boars (Table 1). Some radioactivity was present in the washings but this decreased to a constant level after three or four washes. The sperm concentration in the washings $\left(10^{5}\right.$ spermatozoa $\left./ \mathrm{ml}\right)$ was low compared with the total sperm number $\left(10^{9}\right.$ spermatozoa). Most of the spermatozoa present in the washings were damaged; thus the radioactivity present in the final washing was probably due to disintegrating spermatozoa.

Table 1. Differential binding of labelled basic protein fraction to boar spermatozoa

\begin{tabular}{|c|c|c|}
\hline & Intact boars & $\begin{array}{l}\text { Vesiculectomized } \\
\text { boars }\end{array}$ \\
\hline No. of boars & 2 & 3 \\
\hline Samples incubated & 8 & 10 \\
\hline $\begin{array}{l}\text { Mean specific radioactivity of spermatozoa } \\
\left(\text { ct } \sec ^{-1} / 10^{8} \text { spermatozoa } \pm \text { S.D.) }\right.\end{array}$ & $49 \cdot 6 \pm 7 \cdot 9^{*}$ & $96.9 \pm 10.4^{*}$ \\
\hline $\begin{array}{l}\text { Radioactivity ratio } \\
\text { (final wash supernatant sperm pellet) }\end{array}$ & $0 \cdot 10$ & $0 \cdot 13$ \\
\hline $\begin{array}{l}\text { Protein level in seminal plasma of ejaculated } \\
\text { semen }\left(\mathrm{mg} \mathrm{ml}^{-1}\right)\end{array}$ & $39 \cdot 7$ & $4 \cdot 3$ \\
\hline
\end{tabular}

\section{Proteins binding to sperm membranes}

The radioactivity of the labelled proteins was mainly associated with two bands which equilibrated at relative densities of $1 \cdot 150$ and $1 \cdot 165$ (Text-fig. 3). Electron micrographs of these bands revealed that they consisted mainly of membrane vesicles (Plate 1 ). 


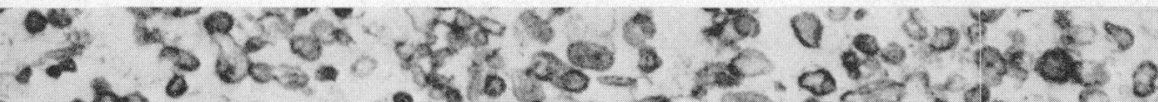

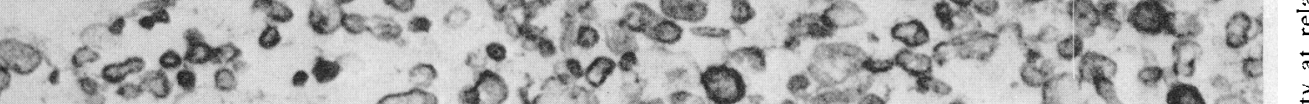

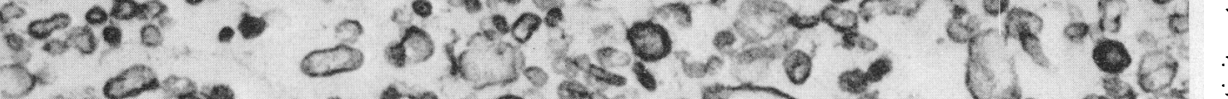

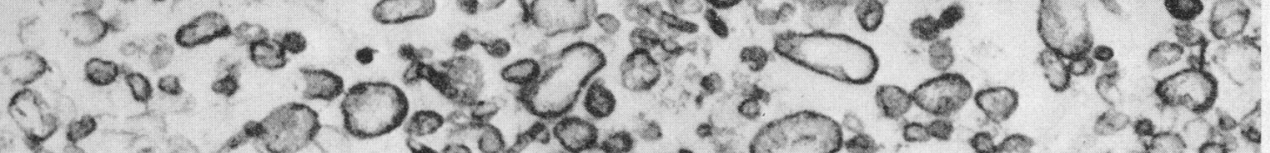

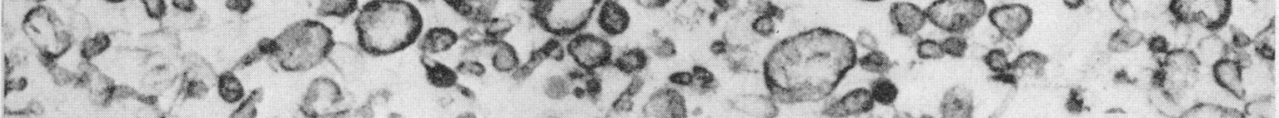

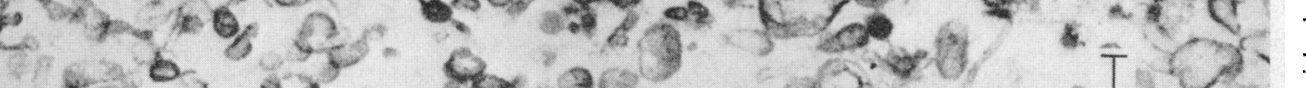

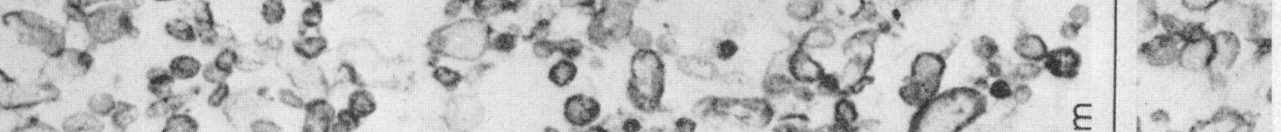

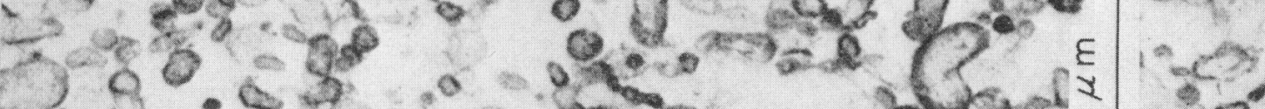

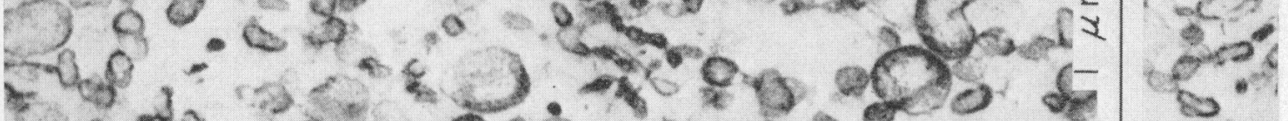

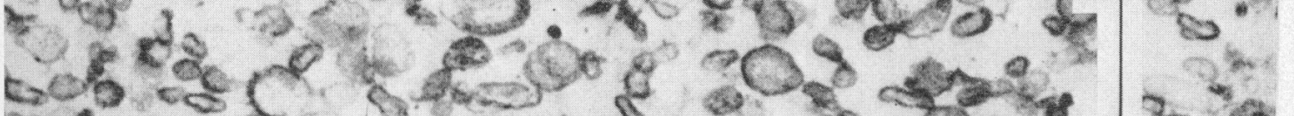

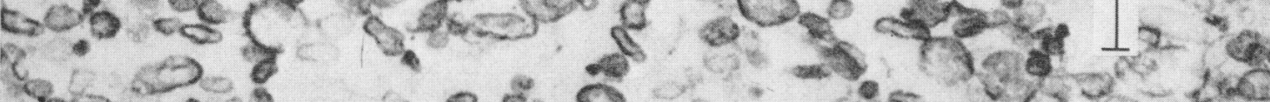

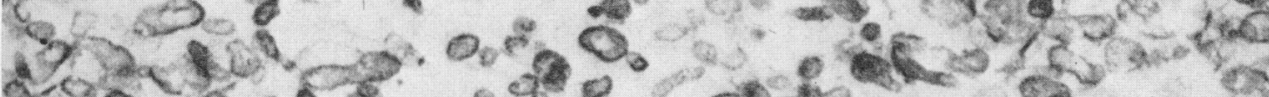

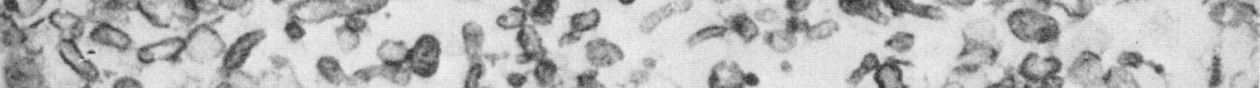

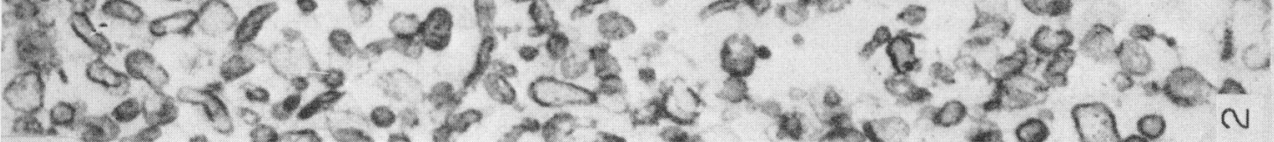

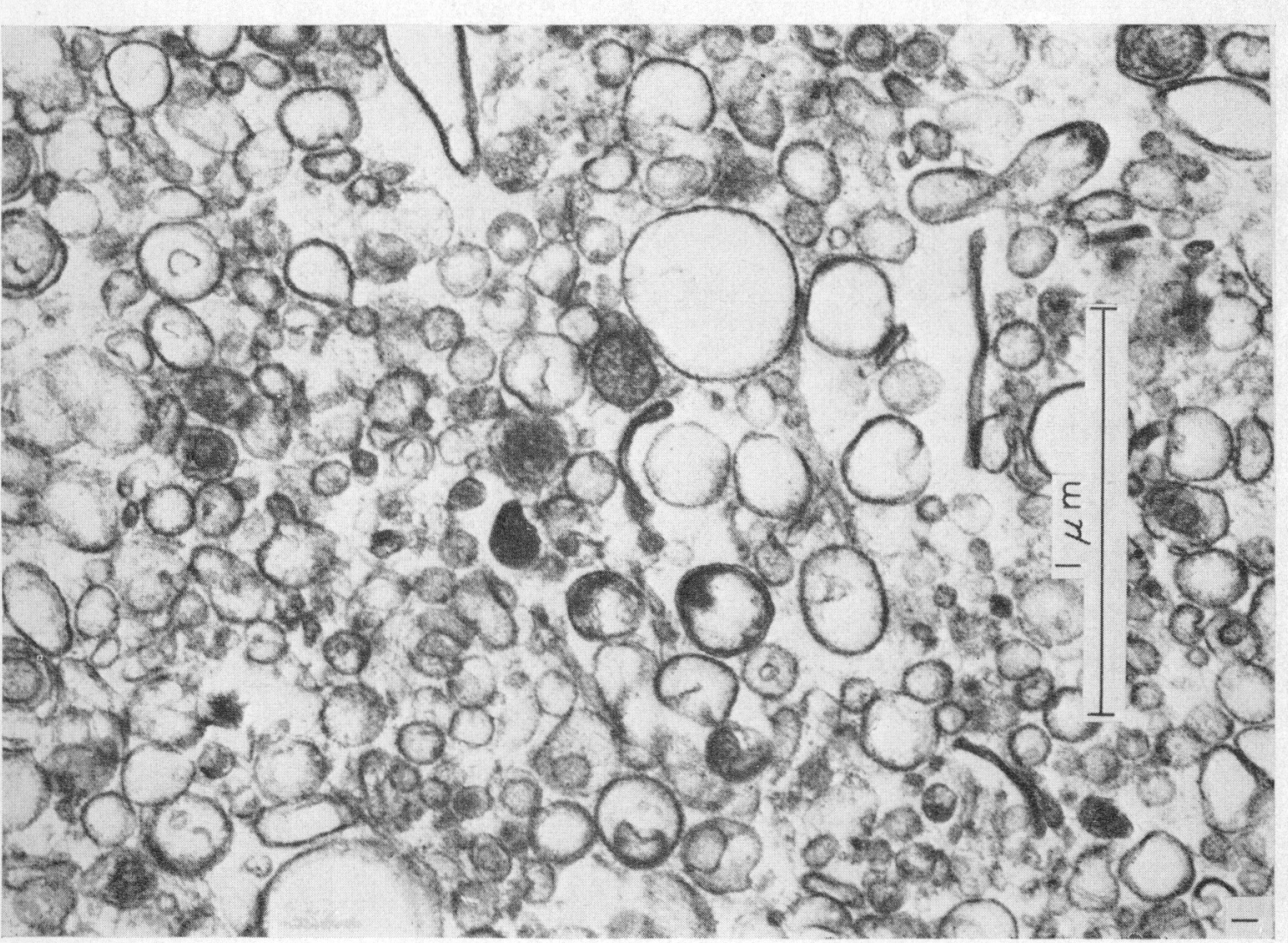




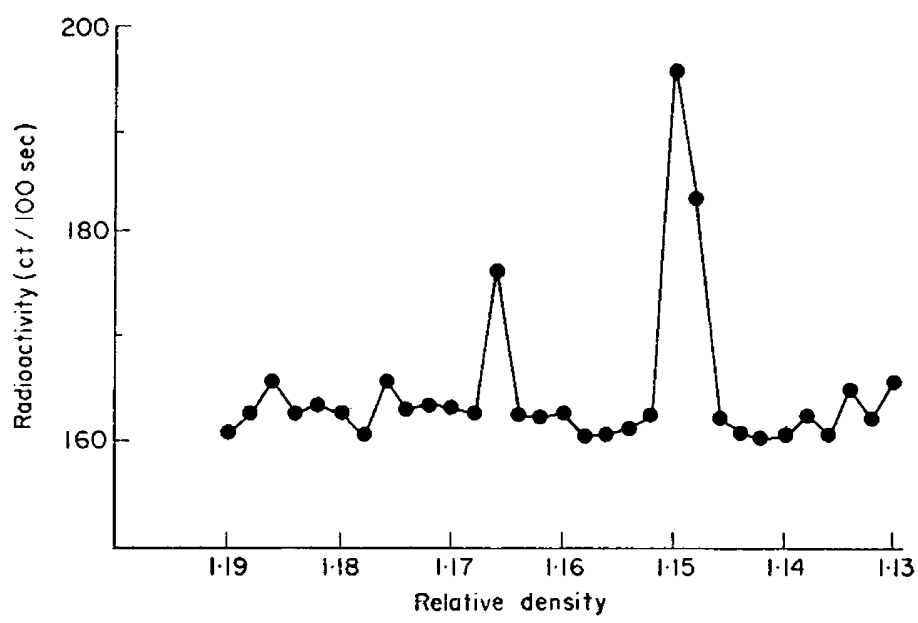

Text-fig. 3. Radioactive plot of the density gradient fractionation of incubated sperm membrane from a vesiculectomized boar.

\section{Discussion}

Twice as much (197\%) labelled seminal plasma protein became bound to spermatozoa from boars without seminal vesicles than to normal boar spermatozoa after incubation at $30^{\circ} \mathrm{C}$. This probably reflects the greater number of cationic binding sites available on spermatozoa from vesiculectomized boars. In a normal ejaculate, spermatozoa are already coated with seminal vesicle proteins, thereby reducing the available binding sites. The association of the radioactively labelled proteins with the membrane vesicles suggests that the outer membranes of the spermatozoa (plasma and acrosomal) are areas of attachment of the seminal plasma basic protein.

It is unclear why two separate membrane bands, both associated with a label, were isolated by the methods used. The homogenization technique was devised to remove plasma and acrosomal membranes from the spermatozoa while leaving the nucleus intact. Electron micrographs of the sperm pellets after centrifugation revealed that most cells had an intact nuclear membrane. This would suggest that the two bands consisted of plasma and acrosomal membrane attached to labelled protein, although one cannot entirely discount the presence of some nuclear membrane material in the preparation. Detergents were not used to specifically remove acrosomes from the spermatozoa (Lunstra et al., 1973), as it was felt that these chemicals could lead to configurative changes of the membrane proteins.

Binding of labelled seminal plasma proteins to the membranes accords with the results of Boursnell \& Coombs (1966) who suggested that seminal plasma proteins were being absorbed by the spermatozoa. If the membrane surface charge of epididymal spermatozoa is negative (Yanagimachi et al., 1972), then basic proteins would be absorbed by electrostatic attraction. Isoelectric focusing studies (Moore \& Hibbitt, 1975) have shown that the isoelectric point (i.e.p.) of normal ejaculated boar spermatozoa is higher than that of spermatozoa from vesiculectomized boars even after washing (i.e.p. $\mathrm{pH} 6.5$ and 4.5 respectively). The change in isoelectric points suggests that considerable 'sperm coating' occurs at ejaculation.

Several workers have shown that seminal plasma has a detrimental effect on spermatozoa of different mammals during cooling procedures and cold shock. Fulka et al. (1965) showed that bovine spermatozoa from the ampulla became sensitized to cold shock after treatment with the fluids of the seminal vesicles. Antisera to seminal vesicle fiuid reduced this effect when added to ampullary spermatozoa before contact with seminal vesicle fluid, but had no effect on ejaculated spermatozoa (Matousek, 1964). In our study, a certain amount of protein was bound to the boar spermatozoa and could not be removed even after extensive washing, indicating a probable irreversible attachment 
of the protein to the membrane. The iodinated basic protein fraction contained more than one component, as revealed by gel electrophoresis (Text-fig. 2) and isoelectric focusing (unpublished results), and it was not possible to ascribe the 'sperm-coating' to one particular protein.

Boar spermatozoa are also susceptible to cold shock (Polge, 1956) and seminal plasma could be detrimental to them on cooling to $5^{\circ} \mathrm{C}$ (Pursel et al., 1972). If basic proteins from the seminal vesicle glands bind to the spermatozoa, as the results would suggest, then damage to the spermatozoa on cooling may be due to membrane breakdown induced by stresses of cooling enhanced by basic proteins.

The authors acknowledge the assistance of Mrs P. Bland and other members of the Department of Cellular Pathology for the electron micrographs, and the financial support of the Meat and Livestock Commission to H.D.M.M. for a studentship.

\section{References}

Boursnell, J.C. \& Briggs, P.A. (1969) Boar seminal plasma proteins. II. Electrophoretic identification of the haemagglutinin. J. Reprod. Fert. 19, 157-166.

BOURSNELL, J.C. \& CoOMBS, R.R.A. (1966) A haemagglutinating factor in boar seminal plasma. $J$. Reprod. Fert. 11, 139-144.

Davies, C., Hibitt, K.G., Hall, G. \& Moore, H.D.M. (1975) The removal of the seminal vesicle glands from the boar and the effects on the semen characteristics. J. Reprod. Fert. 43, 305-312.

Drew, M. \& McLaren, S. (1970) The effect of histones and other basic macromolecules on cell permeability and elongation of barley roots. Physiologia Pl. 23, 544-560.

Fulka, J., Surcova, H. \& Valenta, M. (1965) Protein polymorphism of the seminal vesicles of bulls and the sensitivity of bull spermatozoa to cold shock. Proc. 9th Europ. Anim. Blood Group Conf. pp. 381-386.

HaNCock, J.L. \& Hovell, G.L.C. (1959) The collection of boar semen. Vet. Rec. 71, 664-665.

Hathaway, R.R. \& HARTRe, E.F. (1963) Observations on the mammalian acrosome. Experimental removal of acrosomes from ram and bull spermatozoa. $J$. Reprod. Fert. 5, 225-232.

HibBITT, K.G. \& Benians, M. (1971) Some effects in vivo of the teat canal and effects in vitro of cationic proteins on staphylococci. J. gen. Microbiol. 68, 123-128.

Hunter, W.M. \& Greenwood, F.C. (1962) Preparation of iodide-131 labelled human growth hormone of high specific activity. Nature, Lond. 194, 495-496.

LAvoN, U. \& BoursnelL, J.C. (1971) Characterization of boar seminal plasma, vesicular secretion and epididymal plasma proteins by gel disc electrophoresis and isoelectric focusing on polyacrylamide. J. Reprod. Fert. 27, 227-232.

LAYNE, E. (1957) Protein estimation by ultraviolet absorption. In Methods in Enzymology, Vol. III, pp. 451-454. Eds S. P. Colwick \& N. O. Kaplan. Academic Press, New York.
Lunstra, D.D., Clegg, E.D., Morre, D.J., WilliamSON, F.A. \& MALVEN, P.V. (1973) Isolation of plasma membranes from porcine sperm. Fedn Proc. Fedn Am. Socs exp. Biol. 32, 284.

MatouseK, J. (1964) Antigenic characteristics of spermatozoa from bulls, rams and boars. III. Absorption analysis, precipitins and fructolysis in relation to the antigenicity of bull spermatozoa. J. Reprod. Fert. 8, 13-21.

Mozllering, H. \& Gruber, W. (1966) Determination of citrate with citrate lyase. Analyt. Biochem. 17, 369-379.

MOORE, H.D.M. \& HibBitT, K.G. (1975) Isoelectric focusing of boar spermatozoa. J. Reprod. Fert. 44, 329-332.

Nelson, M. \& Boursnell, J.C. (1966) Studies on boar seminal plasma proteins. IV. Isolation of factors with haemagglutinating and protein-precipitating activity. Biochim. biophys. Acta 117, 144-156.

Polge, C. (1956) Artificial insemination in pigs. Vet. Rec. 68, 62-78.

Pursel, V.G., Johnson, L.A. \& Rampacek, G.B. (1972) Acrosome morphology of boar spermatozoa incubated before cold shock. J. Anim. Sci. 34, 278-283.

RoBerts, T.K., Boursnell, J.C. \& Brown, A.D. (1974) The rôle of zinc in promoting the opalescence and cold precipitation of boar seminal plasma. II. Relationship of a zinc-precipitable protein with the haemagglutinin. J. Reprod. Fert. 37, 373386.

Ryser, J.J.-P. \& HANCOCK, R. (1965) Histones and basic polyamino acids stimulate the uptake of albumin by tumour cells in culture. Science, N.Y. 150, 501-503.

Weil, A.J. \& FinkLer, A.E. (1958) Antigens of rabbit semen. Proc. Soc. exp. Biol. Med. 98, 794-797.

YaNAGIMACHI, R., NodA, Y.D., Funmoto, M. \& Nicolson, G.L. (1972) The distribution of negative surface charges on mammalian spermatozoa. Am. J. Anat. 135, 497-520. 